\title{
Informasjon må individualiseres
}

En gruppe medisinstudenter i Trondheim har, prisverdig nok, interessert seg for hvilken informasjon som utveksles når unge kvinner får p-piller første gang. Resultatene publiseres i dette nummer av Tidsskriftet (1). De drøfter utfordringen det er å gi tilstrekkelig informasjon og prioritere det viktigste - man må unngå at det drukner i alt det man ønsker å formidle. I moderne medisin kan dette være et dilemma. Forfatterne ønsker standardiserte retningslinjer for optimal håndtering av førstegangsforskrivning av p-piller. Det er en dårlig idé. Spørsmålet er ikke «Hvor mye informasjon må jeg gi når jeg forskriver p-piller?», men «Hvilken informasjon setter akkurat denne pasienten i stand til å håndtere sitt behov for prevensjon på beste måte?».

Kjernepunktet er individualisering, og her svikter det. Under kommunikasjonstrening og på videoer fra konsultasjoner har jeg gang på gang observert at legenes muntlige informasjon mest likner opplesning fra en brosjyre. Fremføringen er sjelden entusiastisk den viser at legen er god til å huske mer enn den er opplysende for pasienten. Kanskje kjeder legen seg? I alle fall er det mye som ikke blir tatt imot - svært ofte klager leger over at pasientene ikke husker hva som er blitt dem fortalt. Altså må noe gjøres annerledes. Veien til å forbedre den lite hensiktsmessige oppramsingen er å supplere anamneseopptaket i begynnelsen.

I tillegg til ordinær sykehistorie må legen uansett problemstilling nemlig skaffe seg informasjon om tre forhold: Hva tenker du om dette? Hvordan påvirker dette dagliglivet ditt? Hva håper du at vi kan oppnå? Overført på situasjonen med førstegangsforskrivning av p-piller innebærer dette at legen må danne seg et bilde av hva den unge kvinnen vet om pillen og hvorfor hun tror eller mener at den er den beste prevensjonen for henne i den aktuelle situasjonen. Først når legen på denne måten setter seg inn i den enkeltes situasjon, ligger forholdene til rette for å gi skreddersydd informasjon. Det blir lettere å velge hvilke fakta man skal bruke tid på å diskutere og hva man kan legge til side. Dette handler om å se pasientperspektivet, et anerkjent prinsipp i moderne lege-pasient-kommunikasjon (2). Det finnes ikke noe «one-size-fits-all» når informasjon skal formidles.

Det tar tid å gi god informasjon. Årsaken er at legen må forholde seg til mottakerens prosesseringshastighet. Pasientene er ofte i en sårbar situasjon, og følelser er nesten alltid aktivert. Det gir dårligere mottaksforhold. Informasjonen de skal forholde seg til, kan være kompleks og vil regelmessig handle om begreper og alternativer i et landskap de ikke er vant til å befinne seg i. Ofte vil fakta være forbundet med usikkerhet. Derfor hører det til prosessen å dele opp informasjonen i passende munnfuller og vente med påfyll til man ser at pasienten har svelget unna. Etterpå må man forsikre seg om at kjerneinformasjonen er mottatt. Tidligere ble det gjerne anbefalt at legen summerte opp, men etter hvert er man kommet frem til at det fungerer bedre at pasienten gjør dette, så legen kan få korrigert feiloppfatninger. À diskutere usikkerhet og sjekke hvordan pasienten har oppfattet informasjonen gjøres i under $5 \%$ av amerikanske konsultasjoner (3), og det er liten grunn til å tro at situasjonen er bedre i Norge. I vår kommunikasjonsundervisning anbefaler vi at legen bruker halvparten av tilgjengelig tid med pasienten til å gi informasjon og til å avslutte konsultasjonen.

Det gis ofte for mye informasjon, i form av detaljer om diagnostikk eller rasjonale for behandlingen som i liten grad setter pasienten bedre i stand til å ta vare på helsen sin eller gjøre informerte valg. Hovedsakelig er det to grunner til det. Hvis legen har dårlige nyheter, er oppgaven så smertefull at ønsket om å reparere fører til sukring av pillen med modifisering av budskapet eller vektlegging av alt som kan gjøres for å avhjelpe situasjonen (4). Budskapet blir uklart. Det må heller settes av tid så raskt som mulig etterpå når pasienten har fått summet seg, om mulig med en pårørende til stede. Ekstra informasjon må gis som respons på pasientens spørsmål, ikke for å døyve legens ubehag.

Den andre årsaken til for mye informasjon er en bivirkning av pasientrettighetsloven $\S 3.2$, om retten til informasjon, og den tilhørende forskriften om pasientjournal (§ 8 i) (5), som krever at hovedinnholdet $\mathrm{i}$ informasjon gitt til pasienten må dokumenteres. Leger er engstelige for klager på at de har gitt for lite informasjon, og det leder til overinformasjon og overdokumentasjon. Faglig forsvarlighet må være rettesnoren, og institusjoner bør velge en ny strategi for å svare på lovkravene. Den bør innebære regelmessig etterutdanning i og supervisjon av legenes muntlige kommunikasjon som ledd i forbedring av behandlingskvaliteten. Leger som driver egen praksis, må på samme måte kvalitetssikre ferdighetene sine.

Skriftlig informasjon kombinert med muntlig fungerer gjerne best (6), og leger kan med fordel utarbeide en liten liste over risikoer de mener pasienten bør kjenne til. Den må være kort nok til å kunne leses under konsultasjonen, og det er fint om pasienten får anledning til å stille spørsmål til punktene. Men skriftlig informasjon kan aldri erstatte dialog. Formålet må være å styrke pasientens egenomsorg, ikke skaffe seg selv ryggdekning. Gode informasjonsrutiner vil sannsynligvis redusere antall klagesaker $(7,8)$. Men det viktigste er at pasientene vil være bedre hjulpet.

\section{Pål Gulbrandsen}

pal.gulbrandsen@ahus.no

Pål Gulbrandsen (f. 1955) er seniorforsker ved Akershus universitetssykehus og førsteamanuensis ved Universitetet i Oslo.

\section{Litteratur}

1. Sandø AD, Aanes SG, Slørdal L et al. Rutiner ved førstegangsforskrivning av p-piller. Tidsskr Nor Legeforen 2010; 130: 2344-8

2. Stewart M, Brown JB, Weston WW et al. Patient-centered medicine. Transforming the clinical method. Oxon, England: Radcliffe Medical Press, 2003.

3. Braddock $\mathrm{CH}$, Edwards KA, Hasenberg NM et al. Informed decision making in outpatient practice: time to get back to basics. JAMA 1999; 282: 2313-20.

4. Rogg LV. Communicating medical prognosis. Concepts, attitudes and practice. Doktoravhandling. Oslo: Universitetet i Oslo, 2010.

5. Forskrift om pasientjournal, 21.12.2000 nr. 1385. Oslo: Sosial- og helsedepartementet, 2000.

6. Johnson A, Sandford J, Tyndall J. Written and verbal information versus verbal information only for patients being discharged from acute hospital settings to home. Cochrane Database Syst Rev 2003; nr. 4: CD003716. DOI: 10.1002/ 14651858.CD003716

7. Levinson W, Roter DL, Mullooly JP et al. Physician-patient communication: the relationship with malpractice claims among primary care physicians and surgeons. JAMA 1997; 277: 553-9.

8. Tamblyn R, Abrahamowicz M, Dauphinee D et al. Physician scores on a national clinical skills examination as predictors of complaints to medical regulatory authorities. JAMA 2007; 298: 1057-9. 